Knowledge Creation in Reflective Teaching and Shared Values in Social Education: A Design for an International Classroom

Jonas Christensen, Joachim Thönnessen, Bret Weber 


\title{
Knowledge Creation in Reflective Teaching and Shared Values in Social Education: A Design for an International Classroom
}

\author{
Jonas Christensen ${ }^{a^{*}}$, Joachim Thönnessen ${ }^{b}$, Bret Weber $^{\mathrm{c}}$ \\ ${ }^{a}$ Malmö University, Citadellsvägen 7, Malmö, SE-205 06, Sweden \\ ${ }^{b}$ University of Applied Sciences Osnabrück, Caprivistr. 30a, Osnabrück, DE-49076, Germany \\ ${ }^{c}$ University of North Dakota, 225 Centennial Drive, Grand Forks, ND 58202-7135, USA \\ *Corresponding author: jonas.christensen@mau.se
}

\section{Abstract}

\section{Keywords:}

Reflective Learning; reflexive Learning; social work education; crosscultural perspectives; community of practice; professional identity
This article is based on an international comparative social policy module held annually at Malmö University (Sweden) with partner universities from several countries. Our study examines the results of intra- and interpersonal dynamics among participants and lecturers, which we call "productive tension", in relation to overarching questions about knowledge acquisition and the importance of reflexivity and reflectivity in the learning process. Students and faculty create a "community of practice" (COP) (Lave \& Wenger 1991) that benefits from a continuous interactive environment and direct engagement. Our study uses a mixed method approach. The analysis considers qualitative data from interviews with the participating students and quantitative data from questionnaires. In this article, we focus on the productive tension inherent in the reflective and reflexive processes. Reflective and reflexive processes are identified that influence the students' experience of cross-border cooperation and their professional identity. Our study also demonstrates how the knowledge about "Social Work" as a profession can be broadened through international comparative teaching and learning. The main conclusion of this work is that reflective and reflexive learning processes in social work education enable participants to see and understand themselves from a broader perspective and strengthen their own professional identity.
Zusammenfasung

\section{Schlüsselworte:}

Reflektives Lernen; reflektierendes Lernen; Lernprozesse in der Sozialen Arbeit; interkulturelle Perspektiven, community of practice; professionelle Identität
Dieser Artikel basiert auf einem internationalen, vergleichenden sozialpolitischen Modul, welches alljährlich an der Universität Malmö (Schweden) mit Partneruniversitäten aus mehreren Ländern abgehalten wird. Unsere Studie untersucht die Resultate einer intra- und interpersonellen Dynamik unter den Teilnehmer/innen und Dozent/-innen, die wir als "produktive Spannung" bezeichnen, in Bezug auf übergreifende Fragen zum Wissenserwerb und zur Bedeutung von Reflexivität und Reflektivität im Lernprozess. Studentinn/-en und Dozent/-innen schaffen eine "Community of Practice“ (CoP) (Lave \& Wenger 1991), die von einer dauerhaften, interaktiven Umgebung und einer direkten Beteiligung profitiert. Unsere Studie verwendet einen Ansatz mit gemischten Methoden. Die Analyse berücksichtigt qualitative Daten aus Interviews mit den teilnehmenden Studierenden und quantitative Daten aus Fragebögen. In diesem Artikel wird insbesondere die produktive Spannung thematisiert, die den reflexiven und reflektierenden Prozessen innewohnt. In dieser Studie werden reflexive und reflektierende Prozesse aufgezeigt, die die Erfahrung der Studierenden im Rahmen einer grenzüberschreitenden Zusammenarbeit und ihre berufliche Identität beeinflussen. In unser Studie wird auch demonstriert, wie das Wissen über die Profession "Soziale Arbeit" durch international vergleichendes Lehren und Lernen vergrößert wird. Die Hauptschlussfolgerung dieser Arbeit ist, dass reflexive und reflexive Lernprozesse in der Sozialarbeitspädagogik die Teilnehmenden befähigen, sich selbst aus einer breiteren Perspektive zu sehen und zu verstehen und ihre eigene berufliche Identität zu stärken.

\section{Introduction}

This article reflects on issues and lessons stemming from teaching an international course in a cross-border collaboration with partner-universities from several countries. Set in the environment of a recurrent meeting place, it presents an unfamiliar culture for the majority of the students. The authors also assume the following conditions: Together, students and instructors, create an intentional community of practice $(\mathrm{CoP})$ (Lave \& Wenger 1991), a group of people who share a profession ${ }^{1}$. Discussing international aspects of a topic like Child

${ }^{1}$ In this article a detailed explanation of COP's is given in section 2.2 "The Framework"; 
protection provides a comparative understanding of social policy. Professional skills are reinforced by a comparative understanding of policy systems, alternative possibilities, and the social work profession's role in policy formation.

This article goes further than a previous one (Christensen et al, 2017, pp. 15-20) by seeking to understand the role of reflectivity and reflexivity in emergent knowledge developed in the context of an international classroom. We want to show the impact of this knowledge on social work students' evolving professional identification. With the term reflective learning we mean the processes by which students engage with one another to discuss and learn from one another. In contrast, by reflexivity we mean the process by which students begin applying their emergent knowledge in a more spontaneous fashion. In this manner, the reflexive is almost contrary to the reflective. While the reflective tends to reinforce preexisting beliefs, the reflexive is a manifestation of evolving understanding and an emergent profession identity.

Of specific relevance to this article, $\mathrm{CoP}^{\prime} \mathrm{s}$ contribute to the understanding and development of capacities in connection to policy differences and shared values as it offers a reflective understanding to the meaning of crossborder meetings. We argue that knowledge acquisition among social work students' through cross-cultural meetings and professional identity formation in relation to their reflections, adds global and local (Glocal) ${ }^{2}$ value to social work education. Knowledge acquisition through the stimulation of being in a new meeting place creates a new framework for learning about the social work discipline. For instance, in our CoP, we observed students reflectively focusing on differences between the social policy and practice environments from their home nations. Then, when faced with hypothetical, practice situations, they reflexively engaged in a shared, emergent, professional identity. In the end, this combination of the reflective and reflexive processes within the CoP enlightens students' understanding of policy, contributes to their developing professional identity, and this is all enhanced by trust building over a period of interaction while immersed in a cross-border context.

\footnotetext{
${ }^{2}$ Glocalization (a portmanteau of globalization and localization) is the "simultaneous occurrence of both universalizing and particularizing tendencies in contemporary social, political, and economic systems." The notion of glocalization "represents a challenge to simplistic conceptions of globalization processes as linear expansions of territorial scales. Glocalization indicates that the growing importance of continental and global levels is occurring together with the increasing salience of local and regional levels" (https://en.wikipedia.org/wiki/Glocalization)

${ }^{3} \mathrm{We}$ do not pretend to be the first having the idea to bring these two elements together. Feucht et al (2017) write in their introductory article to a special edition of the „Educational
}

Here, we aim to answer the following research questions: How can reflective and reflexive knowledge creation processes be seen and emerge in the international classroom? How are these processes enhanced by the environment of a cross border CoP? Through participant feedback we highlight the views and experiences of those students who attended the 2018/19 module of the international course. Our starting point in the definition of Glocal knowledge is that it is theoretical, practical, and processual. We show that understanding the concepts of reflexivity and reflectivity can be useful in understanding the students' knowledge construction. ${ }^{3}$ Our work encourages the students to develop their capacity for selfreflectivity as a part of their professional development.

One outcome of a previously published article (Christensen et al, 2017) was that students will become more critical and develop analytical skills and reflectiveness towards their own view of profession by communicating with each other and learn from each other in an international context. Further on, it was shown that Social Work is much bigger than what educators and students learn from their own education at "home", hence the article demonstrated that a continuous cross-border cooperation in Social Work Education, where teachers work closely together within permanent meeting places, provides a beneficial social context for students and teachers. In this, we showed that the evolvement of a Community of Practice was essential as a support for open dialogue within and with outside perspectives. The main conclusion was that out of different learning outcomes, the environmental factoris the 'unique' contribution to knowledge acquisition, and that cooperation encourages the student's capacity for professional, social construction. More specifically, we concluded that prolonged, interactive, and direct engagement in place is essential to the social construction that is foundational to adult learning.

We employ a mixed-methods analysis of course interactions over a two-day period from the 2018/19 course module. Students were first asked to reflect upon, and to then teach one another about the social policy environment and the views of the social work profession in their home nations. This tended toward a focus on differences. Then,

Psychologist" on reflection and reflexivity in Teaching and Teacher Education: „However, reflection on its own does not necessarily guarantee practice that is informed by such reflection. We argue that one way in which we might support reflection for action is to focus on a process known as reflexivity" (Feucht et al, 2017, 234); but we pretend to be among the first who transfer these ideas to learning and teaching in an international classroom; another difference between our view and the view of the Educational Psychologist is that we put our emphasis upon a sociological-interactional, i.e. non-psychologicalepistemological perspective (as Feucht does); 
asked to address case studies, the students' interactions reflectively focused on shared identity, values, and even methods. The shift from reflective differences to reflexive commonalities was nearly seamless. Students submitted reflective group notes from these exercises, and then, days later, completed individual surveys including Likert scaled questions. The data was then transcribed, converted from qualitative to quantitative, and then coded and analyzed thematically to address the research questions. This article utilizes exemplar quotations from that data set to reinforce and illustrate the dominant responses.

\section{Theoretical foundation}

\subsection{Reflexivity and reflectivity - previous research}

The study described in this paper utilizes a theoretical interpretative framework focused on reflexivity and reflectivity in the context of teaching and learning. The work of John Dewey, a pre-eminent educational theorist of the 20th century (Dewey 1934; 1938) is very important here. In his concise and powerful analysis of education, Dewey is critical of teaching methods that are "static" and not incorporating sufficient experiential learning. For Dewey, the main challenge to experience-based learning is to create fruitful experiences for the students. The educators' role in creating educative experiences is mainly to organize these experiences in progression to guide students' learning (Dewey 1938).

We explore the utility and value of some of Dewey's concepts in an adult learning context, and consider if they are sufficient for our purposes. Specifically, we consider whether reflexive and reflective processes adequately address and provide a sufficiently useful framework to describe the knowledge emergence that occurs in the transnational and local context of an international classroom. The following six phases of reflection, which clearly mirror the scientific method, consistently appear in Dewey's writing (Rodgers 2002, p. 851):

1. an experience;

2. spontaneous interpretation of the experience;

3. naming the problems or the questions that arises out of the experience;

4. generating possible explanations for the problems or questions posed;

5. ramifying the explanations into full-blown hypotheses;

6. experimenting or testing the selected hypothesis

As soon as one is in an experience, as well as after an experience, spontaneous interpretation of what is going on ensues. In the initial phases of reflective thought, this interpretation is involuntary. Things leap to mind (Rodgers 2002 , p. 851). Reflection therefore refers to an activity in which an experience is recalled. It is a response that involves the conscious recall and examination of experiences, as a basis for evaluation and as a source for planning and action (Schön, 1983; 1987). It is important to provide time in teaching for discussing students' views about the nature of social work and 'international' influences from their perspective. Building flexibility into curricula and assessments is also useful to allow students to focus on their home countries or others of interest rather than exclusively considering social work in the country in which they are studying (Rasell et al, 2019).

Knowledge creation through the development of mutually productive forms of collaborationbetween teaching and practice, has for a long time been an important issue for educators aswell as practitioners in different sectors of working life (Inkpen 1996; Moen et al 2012). In the social sciences there is also along tradition of criticism of traditional teaching models, and a corresponding interest indifferent models of action-based, collaborative teaching (Bruffee 1993; Nevin 2009; Willingham 2007). In times of Wilhelm von Humboldt "education" meant the development of personal abilities and talents (Schultheis, 2008). In contrast, today's society places less emphasis on the abilities of the individual as such than on specific, verifiable achievements, which are determined according to a certain standard. The focus here is thus on the fulfillment of societal demands, rather than, as Humboldt's ideal would have it, to educate people individually.

Accordingly, traditional models of teaching tend to objectify theparticipants, and are too inflexible, closed, specialized, or of insufficient practical relevance,etc. (Svensson et al, 2002; Toulminen \& Gustavsen, 1996; Gibbons et al., 1994). In contrast, Gärdenfors (2010) talks about meaningful learning from the viewpoint of informal and formal processes directed at learning to understand. This approach gives students strategies and tools to see new patterns. Or, in other words, teaching is about showing students, and motivating them to see, what is taken for granted. Pink (2011) argues that in order for motivation to be meaningful and sustainable over time, it must be based on the internal driving force. Pink differs between the internal driving force as something based on instinct, in the form of the more biological aspects, and the driving forces that the individual has conditionally. It must feel worthwhile and give the individual an inner satisfaction both to be able to carry out the task and to achieve the outcome. In addition, Pink distinguishes between performance and learning objectives and believes that regular performance targets encourage the individual to make it easy for themselves, while learning targets, to a greater extent, encourage the individual to perform better. The difference can also be described as the difference between deep and superficial learning. The notions of deep and superficial learning derive from the seminal work of Marton and Säljö (1976) on surface learning and deep approaches, and the work by Biggs (1987). According to Cohen et al. (2004), deep learning is promoted through applying knowledge, not just leaving it inert. Reconnecting 
with Pink's thinking on superficial learning, Gärdenfors (2010) approach suggests that the deeper the understanding of the learning process, the more the students can generalise their knowledge.

The reflective approach nurtures the ability to (re) build and (re)elaborate creatively the pathways of new understanding. It implies paying attention to routine practices, which, through reflective analysis, assume a different meaning or are perceived under a new light (Martins et al 2015).

One way of expanding a reflective practice is to move towards a practice of reflexivity. Engaging in reflexivity requires critical thought and careful consideration followed by action rooted in understanding. Engaging in mindfulness and introspection with careful and open consideration to the complexity of situations and events that present themselves frequently generates reflexive practice. Where reflection is often individual, reflexivity is decidedly relational. Cuncliffe and Jun (2005) suggests that reflexive practice is guided by three key questions: Whoam I and what kind of person do I want to be? How do I relate to others and to the world around me? How can I practice self-conscious and ethical actions based on a critical questioning of past actions and of future possibilities?

The educational theorist Palmer (1998) says that as teachers, "we teach who we are" (p.2) and that "good teaching can't be reduced to technique; good teaching comes from the identity and integrity of the teacher" (p.10). The teaching process asks us to pay attention to who we are and to have integrity with our inner world because whether we are aware of it or not, we share our values, beliefs and attitudes with our students. For this reason, reflexivity becomes ,paramount as a process that goes beyond reflecting on the more mechanical aspects of practice to include deep attention to individual positioning within social contexts" (Dressman, 1998).

„Reflexivity is an act of self-conscious consideration that can lead people to a deepened understanding of themselves and others, not in the abstract, but in relation to specific social environments also to foster a more profound awareness and of how social contexts influence who people are and how they behave. It involves a person's active analysis of past situations, events, and products, with the inherent goals of critique and revision for the explicit purpose of achieving an understanding that can lead to change in thought or behaviour" (Danielewicz, 2001, p. 155-156).

Reflexivity is a movement from self-awareness to connectedness with other people. It invites students to not only develop a stronger sense of attentiveness to who they are and who they are becoming, but provides an opportunity to also explore other worldviews. Following these deeper questions, leads to the realization that individual experiences are integral to perceiving the world and our connection to it. It is a process that includes attention to beliefs about ontology (the study of what it means to exist) and epistemology (the study of what it means to know). Reflexivity requires attention to an object, while at the same time attending to one's role in how that object is being constructed or constituted (Davies, 2004).

In turn, we also seek a more refined understanding of the best methods to facilitate the transformative experience of learning and professional development of millennial learners.

"I need to understand my own subjective influences (my beliefs, values and attitudes) on that which I am attending to (my topic). For example, if I see the glass as being half empty, what beliefs are at play for me? What about when I see it as half full? To be reflexive requires analysis of that which founded my beliefs and actions and requires a degree of action based on those findings" (Bray et al, 2000)

The practice of reflexivity can help us in developing a more complete awareness as teachers, or what Iba and Sakamoto (2011) calls kizuki, a heightening of cognitive, emotional, and collegial awareness in order to transform beliefs and assumptions about learning and teaching. This can enable teachers to develop and gain ownership over their own teaching and learning because kizuki is not merely given by someone but it is gained by the teachers themselves or by having mediation with others whether by design or by accident (Iba \& Sakamoto, 2011).

\subsection{The Framework}

The modules have focused on comparative social policy studies involving social work students from around the globe. Colleagues from England, Germany and Sweden learn about one another's different welfare traditions, and their "very specific understanding of Social Work" as well as distinct teaching and learning approaches. Originating from two separate bilateral agreements, the module was eventually joined by students and faculty members from across Europe, Africa, Asia, and a group of scholars from Cuba. The 2017 module was the first to be joined by a group from the United States.

For the 2018/19 spring module, sixty-one students and eleven participating instructors came together. The total included eight Swedish students and five instructors, and students and instructors from the University of North Dakota (USA), the University of Lincoln, the University of Dundee and Northumbria University (UK), the University of Applied Science in Osnabrueck and the Catholic University of Applied Science in Muenich/Benediktbeuern 
(Germany), and the University of Salzburg (Austria). In addition, during the second day, seventy-four Swedish social work students participated.

A previous evaluation of the Malmö module considered a perspective called Community of Practice. CoP derives from John Dewey's notions, but the specific concept was first proposed by cognitive anthropologists Lave and Wenger (1990) who defined $\mathrm{CoP}^{\prime} \mathrm{s}$ as a group of people with a common area of interest or a common concern (Christensen et al, 2017, p. 15). Seeing the international classroom as a CoP led to consideration of how communities of practice evolve, and what their purposes and objectives are. Our CoP offers opportunities for open dialogue with outside perspectives, and a focus on the value of learning communities. That earlier study led to a sense that learning in groups, within an international context, and with prolonged real-time interactions both in and out of the classroom should be seen as a key. The empirical findings in this study indicate that international meetings are a key success factor, and that learning through the stimulation of being in a new meeting place and culture creates a particularly useful framework for learning in the International Social Work discipline. Previous knowledge is tied together with new experiences, and the combination provides understanding at a new, professional level of identity.

\subsection{The history of our collaboration}

In anticipation of the 2018/19 course module "Social Work: Social Policy and Welfare Studies" at Malmö University in Sweden, we as teachers and authors started meeting via Skype in 2017/18. The course is an independent course running since 2010 having around 50 Social-work students per year. It'scurriculum aims to developstudents' knowledge and understanding in relation to social policies within a European context, with a particular focus on the relevance for social work and their implications for social work practice. The meetings emerged from the collaborative teaching in the course over the two weeks of the CoP, along with a shared sense that our students were learning something unique that could only be achieved in the direct-contact interactions afforded by coming together for a focused period of time.

More specifically, during the 2017/18 module, the authors had noted the tendency for students to focus on differences between their national policy systems. Consequently, upon returning home, they were most likely to discuss how the social work profession was both structured and viewed differently in their respective countries. While this focus on differences tended to be the student's main take away, as instructors, we witnessed the students' shared, emergent professional values, perspectives, problem-solving approaches, and even methodologies.
The intention of this study is to explore the productive tension that developed amid this apparent contradiction. More specifically, we wished to better understand the emergent knowledge created by the unique circumstances afforded by the international classroom. Developing professionalidentityis akey aim of social work education (Wiles, 2017)and during our first planning session over Skype, we decided to engage an exercise to help us better understand how students construct knowledge in an international classroom, how that leads to their professional understanding and identity as social workers, and, ultimately, the broader implications for international social work education. Social workers are faced with new responsibilities, and it is important for the education to go beyond the national level (Healy, 2008). Nagy and Falk (2000) claim that the impact of ongoing global processes on the social work profession is dramatic and that reformulating the education to include more international and cross-border cultural content is needed. Whilst internationalization of Social Work is a contested idea, it is none the less seen as an evolving and indeterminate project (Harrison \& Melville, 2004).

In preparation for the 2018/19 module, we had the students read Social Work Education in an International Context: Learning from a Cross-Border Cooperation (Christensen et al, 2017) a month prior to their coming together in Sweden. That article was authored by two of this study's authors along with Janet Walker, a social work educator from the University of Lincoln who had previously participated in the Malmö University module for six years. After completing the reading, students were asked to reflect on how the social work profession is structured in their home country and how it is seen and viewed in sense of status and reputation. Further, they were instructed to think about sharing these reflections with their colleagues during the 2018 module. Once they joined with other students in Malmö, they presented their thoughts to their new colleagues and reflected on the differences between their nation's professional systems. Later in the module, they met in mixed-national groups to consider various case studies as a way to reflect on their shared values, perspectives, and methodologies.

After the students completed their informal presentations, the initial reflective portion of the exercise, they were directed to " 1 . Write down that which was most important about your discussion; 2. Focus on differences: what were the most striking differences between the countries; and 3. What did you learn about your own [nation's social policy] system?". This effort to compare and contrast their different systems in a reflective process was documented by each group. Their notes became part of the data set that was later analyzed by the authors.

On the second day, students were put into new mixednational groups, including the original five nations (with 
students who participated in Round One), and new students from Sweden. On the second day, students completed a similar process from the first with the addition of reflexively addressing a case scenario. Due to the large number of Swedish students (who were interacting with the 'international' students for the first time), a morning session included half of the Swedish students, and the whole exercise was then repeated with the second half in the afternoon. The exercise on the second day included the new element of the case studies. The groups began with essentially the same process as the previous day (though this time including their new Swedish colleagues), but then after the reflections on differences they reflexively addressed various case studies. The groups were then asked to consider best processes to address the described situation in the case study; e. g. how in a professional way to make decisions out of priorities. Specifically, they were asked: "1. What is the solution to the presented problem? and 2. What are the shared skills, values, and methods across the different systems?" Again, both at the end of the morning session and at the end of the afternoon session, recorders in each group sought to capture the emergent discussions.

A few days later, students completed individual surveys including Likert scale questions. The Likert scale questions covered student learning of international social policy, reflections on how the course impacted their understanding, the relevance of studying abroad, and the value of the group exercises. Additionally, the survey included open-ended questions requesting general descriptions of what they were learning, how the course impacted that learning, the role of interactions with students from other nations, and what they would like to see changed or added.

A couple of days later, the authors gathered to reflect ontheir personal observations of what had occurred including analysis of the many pages of notes the students had produced. In a day-long session, the authors considered a variety of issues including their own personal, ongoing understanding of the policy differences between the professional systems in which they operate, and a reflective process of what they had learned from the classroom experience, especially in relation to teaching and learning. In addition to initiating the data analysis, they began articulating an outline for this article.

\section{Research methodology}

\subsection{Methods and Empirical Data}

We employed a mixed methods approach to the data analysis. We chose the method of Grounded Theory to

\footnotetext{
${ }^{4}$ Basic Social Processes (BSP's) are pervasive, fundamental patterned processes in the organisation of social behaviours which occur over time and go on irrespective of the conditional
}

analyze students' responses. We used Barney Glasers' Basic Social Processes (BSP; 1978) ${ }^{4}$ where the focus is specifically on the importance of skill development in theoretical sensitivity for developing grounded theory. The analysis was triangulated by considering the qualitative data collected from the group notes, the individual survey data, the observations of the three instructors, and the coding of the data by an analyst brought into the process months after the module. Then, having identified the dominant themes, the authors developed the Grounded Theory approach further, i.e. included the use of exemplar responses to best illustrate the dominant findings. Finally, the responses were transcribed and entered into an Excel spreadsheet where coding allowed the transformation from qualitative data to quantitative data.

When undertaking Grounded Theory using Barney Glaser's method the aim was to identify and develop the core category/-ies that best explains the topic under investigation that the participants in the study are grappling with and how they are attempting to resolve it. It should be noted (and Glaser discusses this at length) that not all core categories are BSP's nor do they need to be. We are not always searching for BSP's when doing GT. BSP's must be durable over time as well as be relevant and patterned in the data as seen from the perspective of the participants. In any casethe BSP's should arise from the data.

Our research seeks to understand knowledge acquisition and how it is generated in the international classroom. Our empirical data consists of discussions initiated by specific questions between the students, written by the students (Tab. 1).

Tab. 1: Questions and Number of Statements

\begin{tabular}{|c|c|c|}
\hline $\begin{array}{l}\text { Qu } \\
\mathbf{e}\end{array}$ & Description & Statements \\
\hline 1 & $\begin{array}{l}\text { To what extent did Malmo social } \\
\text { policy course enhance your } \\
\text { understanding of international social } \\
\text { policy? (Circle below with } 1=\text { not at } \\
\text { all, to } 10=\text { a great deal) }\end{array}$ & 49 \\
\hline 2 & $\begin{array}{l}\text { Can you describe how the course } \\
\text { impacted your understanding? }\end{array}$ & 45 \\
\hline 3 & $\begin{array}{l}\text { To what extent did Malmo social } \\
\text { policy course enhance your } \\
\text { understanding of your home country's } \\
\text { social policy systems? (Circle below } \\
\text { with } 1=\text { not at all, to } 10=\text { a great deal) }\end{array}$ & 49 \\
\hline
\end{tabular}

variation of place (Glaser, 1978). They do not have to solve the topic under investigation they only have to process it. 
4 Can you describe how the course impacted your understanding?

5 How important was the opportunity to study in Sweden and to interact directly with students and professors from other systems? (Circle below with $1=$ not at all, to $10=$ a great deal)

6 In what ways did these interactions occur and do you have additional comments?

7 To what extent was the group exercise regarding system differences and shared solutions to case studies useful to your learning? (Circle below with 1 $=$ not at all, to $10=$ a great deal)

8 What worked well and could be changed

\begin{tabular}{ll}
\hline Ad & Is there anything else you would like to \\
d add?
\end{tabular}

To keep the theoretical considerations and the actual classroom situation closely related in the process of analyzing the data, we employed an approach exemplified in Williams et al (2011). In a mixed methods approach, the data was transcribed, and that process led to the development of a coding manual (Tab. 2).

Tab. 2: Coding Manual

\begin{tabular}{ll}
\hline Code & Description \\
\hline N.--- & Neutral Comment \\
\hline NG.--- & Negative Comment \\
\hline P.--- & Positive Comment \\
\hline IDC & Learned Information from Different Countries \\
\hline DOST & Time Spent in Discussion with Students from Other \\
& Countries \\
\hline LC & Lecture Content \\
\hline LD & Lecture Duration
\end{tabular}

TML Lecture as a Teaching Method

TMI Interaction/Group Work as a Teaching Method

GWL Group Work Location

ISWL International Social Work Learning/Policy
HCSWL Home Country Social Work Learning/Policy

\begin{tabular}{ll}
\hline IPOC & Interactions with Persons from Other Countries \\
\hline SSID & Swedish Student Involvement Duration \\
\hline GDP & Gaining Different Perspectives \\
\hline VRSW & $\begin{array}{l}\text { Understanding the Role/Value of Social Work in } \\
\text { Society }\end{array}$ \\
\hline STR & Doing Same Learning Task Repeatedly \\
\hline DIP & $\begin{array}{l}\text { Depth of Information Provided/Real World } \\
\text { Application }\end{array}$ \\
\hline GCTA & $\begin{array}{l}\text { Existence of Clear Course Goals and Topic } \\
\text { Alignment Throughout Course }\end{array}$ \\
\hline SWR & $\begin{array}{l}\text { Application of Course Knowledge for Social Work } \\
\text { Reform }\end{array}$ \\
\hline OE & Overall Experience
\end{tabular}

The codes were applied to every single statement related to the questions asked (Tab. 3).

Tab. 3: Statements and Coding (questions 1-3, participant 9)

\begin{tabular}{|c|c|c|}
\hline Question & Statement & Coding \\
\hline 1 & $\begin{array}{l}\text { I learned a lot about } \\
\text { international social policy. I } \\
\text { would have wished to get an } \\
\text { overview in the beginning of } \\
\text { the course and what the goal or } \\
\text { aim of the course is }\end{array}$ & $\begin{array}{l}\text { P.ISWL } \\
\text { NG.GCTA }\end{array}$ \\
\hline 2 & $\begin{array}{l}\text { it was a refreshing of the things } \\
\text { I already know about my } \\
\text { country, it was not a lot of new } \\
\text { information for me }\end{array}$ & $\begin{array}{l}\text { N.HCSWL } \\
\text { NG.IDC }\end{array}$ \\
\hline 3 & $\begin{array}{l}\text { it was very interesting to hear } \\
\text { from Bret about the American } \\
\text { system and from Daniel about } \\
\text { comparative states. For me it } \\
\text { was hard to follow Martinas } \\
\text { class }\end{array}$ & $\begin{array}{l}\text { P.LC } \\
\text { NG.LC }\end{array}$ \\
\hline
\end{tabular}

The authors reflected upon the results and found the codes to be consistent with their classroom experience. With participant responses frequently containing multiple viewpoints, the conversion of the qualitative data facilitated the clustering of the descriptive codes. Then, refining the pattern codes and their relationship to one another led to a useful set of codes that were both "all inclusive and mutually exclusive" (Williams et al, 2011, p. 692). 


\subsection{Limitations}

Limitations of the analysis include a lack of diversity in the coding (there was only a single coder) resulting in limited intercoder reliability. However, the emergent themes identified by the independent coder were quickly familiar to, and agreed upon by, the three instructors. Another limit in the study was the tendency for groups to rely on the students from the United States as note takers. While all course work was conducted in English, and all students and instructors were fluent English speakers, there was some hesitancy from those students for whom English was not a first language to take the responsibility of writing up the notes.

Most importantly to the instructors, the discussion we observed was much richer than what we found in the student recordings. Students generally appeared quite animated, focused, and active in the discussions, but then tended to submit only sparse notes. In relation to the first day, providing students with empty notebooks left the process too open-ended. While we did that intentionally, it proved insufficient. There are times that students prefer more specific guidelines and expectations. Additionally, the three questions may have served as useful prompts for the rich discussions, but they failed to provide sufficiently discreet categories for the process of recording the discussions. In summary, while the students seemed engaged and stimulated by the exercise and the ensuing discussion, without any sort of clear assessment or grading process, they put their effort into interacting with one another rather than expending effort into the process of capturing more than brief sentences or bullet points to describe their conversations. While this interactive, reflective learning was what we had intended, it yielded a less robust data set than we had hoped. Ultimately, we reached consensus that we would alter the reporting process in future classes, though we would not change much else in terms of the structure of the assignment. Future iterations of the exercise may have each student submit an individual report. However, the strength of the emergent themes in the current data set suggest that the findings would not be sufficiently distinct.

\section{Results}

The research questions for this study; How can reflective and reflexive knowledge creation processes be seen and emerge in the international classroom? How are these processes enhanced by the environment of a cross border $C o P$ ? focused on knowledge creation in the unique environment of our cross border CoP in relation to the concepts of reflexivity and reflectivity.Students were asked three questions referring to their experiences on the first day (Tab 4).
Tab. 4: Questions and Number of statements

\begin{tabular}{ll}
\hline $\begin{array}{l}\text { Number of } \\
\text { Statements }\end{array}$ & Question \\
\hline 17 & $\begin{array}{l}\text { 1- What was most important in our } \\
\text { discussion? }\end{array}$ \\
\hline 23 & $\begin{array}{l}\text { 2- What were the striking } \\
\text { differences? }\end{array}$ \\
\hline 20 & $\begin{array}{l}\text { 3- What did you learn about your } \\
\text { own system? }\end{array}$ \\
\hline $\mathbf{6 0}$ & Total \\
\hline
\end{tabular}

The data from the first day of the exercise, gathered in the notebooks submitted by the five groups, was coded across thirteen different codes (Tab. 5). This included twenty comments referencing differences between the various international systems. The next two most common references were about social work education (fifteen), and training (fourteen). There were eleven comments about differences in the cost of social work training. The number of responses dropped from there with eight responses concerning child welfare systems and nine about the different roles and perceptions of social workers in society. Codes after that received four or fewer responses.

Tab. 5: Specification of Codification participant responses first day

\begin{tabular}{ll}
\hline Code & Description \\
\hline CW & Child Welfare \\
\hline VRSW & Value/Role Social Workers in Society \\
\hline ED & $\begin{array}{l}\text { Education for Social Work Degrees; } \\
\text { formal schooling }\end{array}$ \\
\hline TR & $\begin{array}{l}\text { Training for Social Work; Practical } \\
\text { Learning; Licensure }\end{array}$ \\
\hline GFS & $\begin{array}{l}\text { Government Financial System; } \\
\text { Financial Aid }\end{array}$ \\
\hline IS & Insurance System \\
\hline HCS & Health Care System \\
\hline PF & Personal Finances of Social Workers \\
\hline CRS & Comparison referencing similarities \\
\hline CRD & Comparison referencing differences \\
\hline LRN & $\begin{array}{l}\text { Stakeholders Learning from Each } \\
\text { other (countries, individuals) }\end{array}$ \\
\hline HP & Helping Professions cited \\
\hline PH & $\begin{array}{l}\text { Personal Health Issues of Social } \\
\text { Workers' Coding }\end{array}$ \\
\hline
\end{tabular}

Due to the larger groups and the added exercise of reflexively addressing the case studies, the notebooks from the second day were coded across thirty-five distinct types of comments. The eight most common references were in relation to codes receiving from twenty-two to forty-six responses. These ranged from the shared approach of 
"Client Centered Problem Solving" with forty-six, along with various policy or professional considerations (drug policy, 28; family counseling, 24; career paths, 24), or matters related to social work education (education systems in different countries, 37; cost of education, 22).

The fact that the practice value of "client centered problem solving' was the most frequent reference supports our hypothesis that, when faced with practice problems in a reflexive process, the students would come together in terms of shared values and methods. For instance, responses included statements like: "Social work is human rights occupation. We need to stand up for the ones who need help and empower them to a better life." and "We all had a similar approach in terms of skills, values, and methods in addressing the case scenario." The next eight sets of references (with responses ranging from eighteen to fourteen) were primarily about specific practice considerations represented in the case scenarios. The remaining nineteen sets of comments received thirteen or fewer references with fourteen receiving fewer than ten.

The data from the forty-nine surveys included comments about both the reflective and reflexive exercises, as well as broader considerations about the CoP. The surveys included eight Likert-scale questions, as well as answers to open-ended questions that were coded across seventeen common themes.

Among the open-ended questions, $57.2 \%$ of the responses were positive about the experience. The $40.7 \%$ that were critical included, as noted earlier, frustrations about "doing same learning task repeatedly" and advocacy and complaints about "Swedish student involvement duration". Otherwise, the top three sets of responses were in relation to "interactions with persons from other countries", "interaction/group work as a teaching method", "international social work learning/policy" and "learned information from different countries".

Positive expressions from the comments were for example: "The course helped me to gain a clear understanding by interacting with other students that experience day-to-day policies in their home country." And, "This experience cannot compare to any other educational experience to date. Learning by experiencing will only deepen the understanding of material. If not for class interactions with other students, this would not have occurred." However, these positive comments were frequently accompanied by comments about their frustrations: "To me, the opportunity to interact with students from different countries, was why I decided to take part in this course. That's why I was disappointed to only have one day with the Swedish students. However, I felt grateful for the opportunity to talk to all the other students."

\section{Discussions}

Most importantly to the instructors, the collaborative discussions we observed during both the reflective and reflexive processes, was richer than what we found in the student recordings. Students generally appeared quite animated, focused, and active in the discussions, but then tended to submit only sparse notes.

In relation to the first day, providing them with empty notebooks left the process too open-ended. While we did that intentionally, it proved insufficient. There are times that students prefer more specific guidelines and expectations. The three questions served as useful prompts for the rich discussions, but failed to provide sufficiently discreet categories for the process of recording the discussions.

On the first day, the students seemed engaged and stimulated by the exercise and the ensuing discussion. However, without any sort of clear assessment or grading process, they put their effort into interacting with one another rather than expending effort into the process of capturing more than brief sentences or bullet points to describe their conversations. While this interactive, reflective learning was what we had intended, it yielded a less robust data set than we had hoped. Ultimately, we agreed we would alter the reporting process in future classes, though we would not change much else in terms of the structure of the assignment. Future iterations of the exercise may have each student submit an individual report. However, the strength of the emergent themes in the current data set suggest that the findings would not be sufficiently distinct.

The second day of the exercise included the most pressing needs for modification. While the second day utilized some of the process from the first day, the inclusion of Swedish students led to distractions and complaints rather than the richer experience we had intended. On the second day, the groups began with the same reflective process of teaching one another about policy and professional distinctions, and they were again asked to respond to the same three questions the groups had responded to on the first day. After engaging that reflective process, groups were then given case studies to reflexively address as a group.

The results on the second day can be quickly summarized in terms of the following three dynamics. The first two dynamics were not particularly fruitful in terms of student learning, but nonetheless instructive in relation to our study. Dynamic one included a degree of rebellion at being asked to answer the same three questions that had been addressed the first day. This was already simmering in the morning session, but then resulted in more explicit rebellion in the afternoon when most of the students were asked to answer the same questions for a third time. As instructors, we urged them to consider that the groups were new each time (since there were two different sets of Swedish students in the afternoon and in the morning)), but this did little to assuage their complaints. The iterative process on day two - which we intended to nurture reflexivity - felt like busy work to the students. Due to a 
lack of supervision and feedback from the instructors - we hoped to give them room for creative self-organization - the students rebelled at completing the same reflective exercise three times. As instructors, we failed to provide adequate context for reflexive thought, and we tried to rush a process that simply needs more time. It had taken multiple experiences for us to come to our own epiphany of their shared, emergent professional identity. We mistakenly thought we could provide a fast-track to a level of understanding that inherently resists being rushed. Further, by trying to create a 'scientific' situation with limited variables, our instruction stifled the larger contextual thinking necessary for reflexivity, and rather than facilitating and providing a guided opportunity we left students feeling angry and frustrated.

The second dynamic concerns the learning environment. Where the first day's discussions had enjoyed the accommodating setting of the collaborative learning classroom, discussions on the second day occurred in a tiring lecture room with rows of fixed, forward-facing seats. About a third of the groups were able to organize themselves in circles, by making use of uncomfortable, but moveable chairs in the stage area at the bottom of the room. The remaining groups found themselves sitting on the tiered landings alongside the fixed seats, or awkwardly facing backwards across the stationary rows.

Despite these disappointments inherent in the first two dynamics, the third dynamic was in some ways the most important feature of the two days. Despite complaints about repetitive assignments, the groups focused on the work of solving the case studies. Despite the previous focus on differences, the groups generally, and quickly, came to a consensus about the best approach for addressing the problems in the case studies. It was in this reflexive process that they most dramatically demonstrated an emergent professional identity with shared values, perspectives, and methods.

\section{Conclusions}

We show how reflective, collaborative cross-border collaborations with students in teaching processes has the strong potential to improve understanding of the social work profession irrespective of cultural, legislative, or political status in partner countries. The experience of learning in different countries further promotes reflection on different perspectives and the relevance of context through exposure to different educators as well as different systems and cultural norms, including events with practitioners and study visits to practice settings providing direct exchange and first-hand experience. The 'international' in our social work course then comes not just from theoretical analysis, but stems intensively from interaction and mobility; from working with new colleague-students, studying at different universities, travelling to different countries, and being exposed to different teaching styles.
The creation of a "Community of Practice based environment" is an essential part of a reflective teaching model. In the process of creating this environment, an individual and collaborative understanding and learning is established, in which the students simultaneously become more open-minded towards their own professional understanding. When students meet in a cross-border collaboration, different kinds of exchanges take place, with social, academic and cultural dimensions. An extension of the CoP can therefore be defined as the theory of Community of Learning and Practices (CoLP) which suggests that campus-based learning in groups could be a key for professional development. Designing a community of learning and practices will renew and develop the crossdisciplinary partnership perspective in social work education.

It is to say that universal challenges in social work call for a focus on internationally shared knowledge. Development of reflective learning processes and activities to support the understanding of this will therefore be more crucial. It is through encounters between people of diverse backgrounds, cultures and frameworks that we are challenged in our notions, not least in learning environments and educational contexts. In theory, teaching is a process in which knowledge is integrated with the surrounding environment, where the learning of specific knowledge or methods go hand in hand. It is difficult to distinguish from the development of the student's own professional identity and actions. Factors such as diversity of meetings with unique users and collaboration between students (and colleagues) are very important in the professionally experienced "meaningfulness". To conclude, reflective and reflexive learning processes in social work education enable participants to see and understand themselves from a broader perspective and strengthen their own professional identity.

\section{Acknowledgments}

The authors would like to thank Misty Tomchuk, who provided research assistance in the preparation of this paper.

\section{Authors note:}

Jonas Christensen, $\mathrm{PhD}$, Assistant Professor, Dept of Social Work, Faculty of Health and Society. Christensen's research interests are focused on Social and Educational Sciences with a special interest in internationalization, learning processes and social welfare.

ORCID:

0000-0003-0428-2001

https://www.researchgate.net/profile/Jonas_Christensen5

Joachim Thönnessen, PhD, Professor, Dept of Soc Work, Faculty of Business Administration and Social Science. Thönnessen's interests are focused on Social Sciences with 
a special focus on social research especially in the field of health related lifestyles and drug addiction.

ORCID:

0000-0001-9282-7627

https://www.researchgate.net/profile/Joachim_Thoennesse

$\mathrm{n}$

Bret Weber, $\mathrm{PhD}$, Associate Professor and the Graduate Program Director, Dept of Social Work. Weber's research interests are focused on social justice issues related to housing and the social, physical and economic environment.

ORCID: 0000-0003-4372-3623

https://www.researchgate.net/scientific-

contributions/2069313011_Bret_A_Weber

\section{References}

Biggs, J. (1987). Student Approaches to Learning and Studying. Melbourne: Australian Council for Educational Research.

Bray, J., Lee, J., Smith, L., Yorks, L. (2000). Collaborative Inquiry in Practice Action, Reflection, and Making Meaning. Sage Publications.

Bruffee, K.A. (1993). Collaborative Learning: Higher Education, Interdependence, and the Authority of Knowledge. Johns Hopkins University Press, Baltimore.

Christensen, J., Thönnessen, J., Walker, J. (2017). Social Work Education in an international context - learning from a cross-border cooperation. Studia Universitatis Moldaviae - Științe Sociale, no. 3 (103), pp. 15-20.

Cohen, L., Manion, L. \& Morrison, K. (2004). A Guide to Teaching Practice. Routledge, Palmer.

Cuncliffe, A., Jun, Jong S. (2005). The need for reflexivity in Public Administration. Administration \& Society, vol. 37, no 2, pp. 225-242.

Davies, M.G. (2004). Multiple voices in the translation classroom. John Benjamins Publ.

Danielewicz, J. (2001). Teaching Selves: Identity, Pedagogy, and Teacher Education. State University of New York Press.

Dewey, J. (1934). The Need for a Philosophy of Education; in: John Dewey, Art as Experience. New York, Capricorn Books, 1939, pp. 35-57.

Dewey, J. (1938): Experience and Education.New York, NY: Kappa Delta Pi;Collier Books (1963), NY

Dressman, M. (1998). Confessions of a methods fetishist: Or the cultural politics of reflective non engagement. In: Chavez, R. C. \& O'Donnell (eds.): Speaking the unpleasant: The politics of (non)engagement in the multicultural terrain, pp. 108-126; Albany: State University of New York Press.
Feucht et al (2017). Moving Beyond Reflection: Reflexivity and Epistemic Cognition in Teaching and Teacher Education. In: Educational Psychologist, Vol. 52 - Issue 4: Changing Epistemic Cognition in Teaching and Teacher Education: A Focus on Reflection and Reflexivity, pp. 234-241.

Glaser, B.G (1978). Theoretical sensitivity: Advances in the methodology of grounded theory. Mill Valley, CA: Sociology Press.

Gibbons et al. (1994).The New Production of Knowledge: The Dynamics of Science and Research in Contemporary Societies. Thousand Oaks, CA: Sage Publications.

Gärdenfors, P. (2010). Lusten att förstå "The desire to understand". Stockholm: Natur \& Kultur. (In Swedish).

Harrison, G. \& Melville, R. (2010). Rethinking social work in a global world. Palgrave Macmillan.

Healy, L. (2008). International Social Work: Professional Action in an interdependent world. Oxford/New York: Oxford University Press, pp. 43-47.

Iba, T. \& Sakamoto, M. (2011). Learning patterns III: A pattern language for creative Learning. Proceedings of the 18th conference of Pattern Languages of Programs (PloP). ACM-Digital Library, pp. 1-8.

Inkpen, A.C. (1996). Creating Knowledge through Collaboration. In: California ManagementReview, Vol.39, No 1, Fall 1996, pp. 123-140.

Lave, J. \& Wenger, E. (1991). Situated Learning: Legitimate Peripheral Participation. Cambridge. Cambridge University Press (first published in 1990 as Institute for Research on Learning report 90-0013).

Marton, F. \& Säljö, R. (1976). On qualitative differences in learning. I. Outcome and Process. In: British Journal of Educational Psychology, 46 (1), pp. 4-11.

Martins, A. O., Coimbra, M.N., Pinto, I. \& Serradas, R. (2015). How Teachers Experience Practical Reflectivity in Schools: A Case Study. In: American Journal of Educational Research, Vol. 3, No. 7, pp. 918-922.

Moen, A., Morch, A. \& Pavola, S. (eds.) (2012). Collaborative Knowledge Creation, Practices, Tools, Concepts. Sense Publishers, Rotterdam/Boston/Taipei.

Nagy, G. \& Falk, D. S. (2000). Dilemmas in international and cross-cultural social work Education. In: International Social Work 43, pp. 49-60.

Nevin, A. I., Thousand, J. S., \& Villa, R. A. (2009). Collaborative teaching for teacher educators-What does the research say?Teaching and Teacher Education,25(4), pp. 569-574.

Palmer, J.A. (1998). Environmental education in the 21st century: Theory, practice, progress, and promise. New York: Routledge.

Pink, D. (2011). Drive The Surprising Truth About What Motivates. London, Riverhead Books. 
Rasell, M., Join-Lambert, H., Naumiuk, A., Pinto, C., Uggerhoj, L. \& Walker, J. (2019).Diversity, dialogue, and identity in designing globally relevant social work education. In: Social Work Education, 38:6, pp. 675688.

Rodgers, C. (2002). Defining Reflection: Another Look at John Dewey and Reflective Thinking. In: Teachers College Record, 104(4), pp. 842-866.

Schön, D. (1983). The Reflective Practitioner: How professionals think in action. London, Temple Smith.

Schön, D. (1987). Educating the Reflective Practitioner. San Francisco, Jossey-Bass.

Schultheis, F. (ed.). Humboldts Albtraum. Der BolognaProzess und seine Folgen. UVK, Konstanz 2008. (In German).

Toulminen, S. \& Gustavsen, B. (1996). Beyond Theory: Changing Organizations ThroughParticipation. In:Amsterdam: John Benjamin Publishing Company.

Williams, T., Sanchez, B., Hunnell, J. (2011). Aligning theory with practice: Understanding school-family partnerships at an inner-city high school. In: Children and Youth Services Review V. 30, pp. 689-697.

Wiles, F. (2017). Developing social work students' professional identity: the role of England's Professional Capabilities Framework. In: European Journal of Social Work, Vol. 20, pp. 349-360.

Willingham, D. T. (2007). Critical thinking: Why is it so hard to teach? American Educator, 31(2), pp. 8-19. 